Does a Therapeutic Court Context Matter?: The Likelihood of Imprisonment for Indigenous and Non-Indigenous Offenders Sentenced in Problem-Solving Courts

(International Journal of Law, Crime and Justice)

Dr Samantha Jeffries

Dr Christine E.W. Bond 


\title{
Does a Therapeutic Court Context Matter?: The Likelihood of Imprisonment for Indigenous and Non-Indigenous Offenders Sentenced in Problem-Solving Courts
}

\begin{abstract}
A key aspect of the focal concerns perspective of sentencing is that time and information restrictions within the courtroom create the conditions under which perceptual shorthands may impact sentencing determinations. These shorthands are based stereotypes related to offender characteristics including minority group statuses (i.e. ethnicity, race, Indigenous status) (Steffensmeier et al., 1998). To date, sentencing scholars drawing on the focal concerns perspective have only considered the impact of minority group statuses on sentencing in the mainstream courts (Mitchell, 2005; Spohn, 2000). Utilizing multiple regression techniques the current paper explores the impact of Indigenous status on the decision to imprison in the problem solving courts of South Australia. Unlike the mainstream courts, sentencing determinations within the therapeutic problem-solving court environment involve a more extensive examination of offenders and their cases and by extension, perceptual shorthands should be less influential. Evidence supporting this argument is provided by the current research. Results show a direct relationship between Indigenous status and the likelihood of imprisonment, with leniency being extended to Indigenous offenders.
\end{abstract}

\section{Key words}

Focal concerns, sentencing, problem solving courts, minorities 


\section{Introduction}

The question of inequality in sentencing outcomes has been the subject of extensive investigation. In the United States, where the vast majority of sentencing studies are undertaken, the focal concerns perspective (which also borrows from research on attributions to explain sentencing disparities) is currently the most popular framework used to guide research. Focusing on the micro-social context of the court, this approach argues that judicial sentencing decision are driven by three focal concerns: (1) offender blameworthiness; (2) risk (community protection); and (3) practical constraints and consequences (Johnson, 2003; Steffensmeier et al., 1998).

The focal concern of blameworthiness centers on judicial assessments of defendant culpability and the degree of harm caused by their offending. This focal concern is guided by the sentencing philosophy of retribution. It is punishment-focused and firstly requires that the seriousness of an offence be balanced by the imposition of a punishment proportional to the criminal harm caused (Steffensmeier et al., 1998). Judicial assessments of blameworthiness focus on defendants' current and past criminality including: the seriousness of the current offences committed, prior criminal history, offending antecedents (Jeffries and Bond, 2009).

As a rule, offence seriousness is appraised using statutory offence classifications and prescribed sentencing penalties (Steffensmeier et al., 1998). Further, being convicted of multiple offences likely influences judicial perceptions of crime seriousness (Bond and Jeffries, 2011d; Jeffries and Bond, 2009). Offenders' criminal histories may affect estimations of blameworthiness (e.g. perceptions of culpability are likely inflated by repeat offending). Criminal antecedents that may influence assessments of blame typically include offenders' health statuses, substance abuse and victimization histories. For instance, 
blameworthiness may be reduced for those who have: offended in response to being victimized themselves, substance abuse problems, poor mental health. (Allen, 1987; Ashworth, 1995; Bond and Jeffries, 2011d; Hagan, 1975; Jeffries, 2002a, 2002b; Jeffries and Bond, 2009).

The focal concern of risk (or community protection) draws on aspects similar to the focal concern of blameworthiness. However, it is argued that this focal concern is distinguishable from blameworthiness because concepts of risk are underpinned by the sentencing philosophies of incapacitation and deterrence, the ultimate aim of which is community protection (Jeffries and Bond, 2009; Johnson, 2006; Steffensmeier et al., 1998). This means that the focal concern of risk (or community protection) involves judicial predictions pertaining to the future dangerousness of an offender, so it is concerned with an offender's impending behaviour (Bond and Jeffries, 2011d; Jeffries and Bond, 2009). Judicial officers will make predictions about the risk offenders pose to the community based on factors such as current crime seriousness and criminal history (Jeffries and Bond, 2010; Mitchell, 2005; Spohn, 2000; Steffensmeier et al., 1998). Additionally, offender characteristics such as familial situation, employment status, and substance abuse may be considered (Daly, 1994, 1989; Eaton, 1986; Jeffries and Bond, 2010; Jeffries et al., 2003; Kruttschnitt, 1982). For example, risk may be reduced for offenders who are employed and/or have stable family relationships/responsibilities because these factors denote increased levels of informal social control (Daly, 1989; Jeffries, et al., 2003; Jeffries, 2002a, 2002b; Kruttschnitt, 1982). While drug abuse may reduce perceptions of blame (the first focal concern) it may also act as an indicator of re-offending risk. More specifically, if substance abuse is a criminal antecedent and is not 'dealt with' then the risk of future offending and thus community harm is increased (Jeffries and Bond, 2009). 
Finally, practical constraints and consequences involves the consideration of a range of offender constraints and costs (such as the capacity of an offender to 'do time'; the disruption of family care responsibilities), as well community or political expectations that may impact the court's general societal standing (Johnson et al., 2008; Steffensmeier and Demuth, 2000; Steffensmeier et al., 1998, Ulmer et al, 2007).

Judicial focal concerns are further shaped by the organizational constraints within the court environment (Steffensmeier and Demuth, 2006). Sentencing decisions are frequently made under tight time restrictions. This can lead to a lack of comprehensive and reliable information on aspects of defendants' circumstances being made available to judicial officers. Alternatively, information that is conflicting or too detailed may be difficult to disentangle given the time constraints of the decision-making process (Kramer and Ulmer, 2002; Steffensmeier et al., 1998). These conditions may produce a reliance on 'perceptual shorthands' that allow judicial officers to manage the information and uncertainty of the decision making process (Johnson et al., 2008; Steffensmeier and Demuth, 2000; Steffensmeier et al., 1998, Ulmer et al, 2007. These short hands are based on stereotypes and perceptions related to offender characteristics such as race, sex and age; entering the decision-making process through images or attributions that those who belong to these groups are more dangerous, criminal or risky than others (Hawkins, 1981; Steffensmeier et al., 1998). This tendency to make racialized, gendered and aged based assumptions in response to time pressures within the court environment has, according to the focal concerns perspective, led courts in the United States to treat 'young black/Latino male' as a perceptual shorthand for being crime-prone and dangerous (Steffensmeier et al., 1998). 
Similarly, attributions attached to age, gender and race/ethnicity may impact judicial assessments with regard to practical constraints and consequences. For example, research suggests that judges attach a higher social cost to women's imprisonment than men's because of assumptions regarding the superiority of women’s care-giving capacities (Jeffries, 2002a, 2002b). There may be a judicial perception that certain types of offenders are less able to ‘cope with prison’ and thus, a sentence of imprisonment would be unduly harsh (e.g. young people and the elderly) (e.g. Wu and Spohn, 2009)

Thus the time poor environment of the sentencing courts could allow perceptual short hands to infiltrate the sentencing process. In modern western societies, judicial officers in the mainstream criminal court system face increased workloads combined with pressure to ensure a regular case flow through the court and avoid 'backlogs' in sentencing (Johnson, 2003; Steffensmeier et al., 1998; Mackenzie, 2005). With insufficient time to consider the cases before them, according to the focal concerns perspective, stereotyping and thus potential discrimination is likely (Johnson, 2006; Steffensmeier et al., 1998).

The current paper considers sentencing outcomes for Indigenous versus non-Indigenous offenders in Australia's problem solving (i.e. drug courts, mental impairment and family violence courts) to explore the influence of therapeutic courtroom organizational contexts (and by proxy time) on sentencing disparity. As will be discussed more fully below, in contrast to the 'pressure cooker' environment of the mainstream courts, sentencing in the problem solving courts involves a more extensive examination of offenders and their cases. By extension, within the problem solving courts, judicial reliance on perceptual shorthands should be minimized, as well as direct sentencing disparity. 


\section{Race, Ethnicity and Indigeneity: Prior Research, Focal Concerns and Sentencing in the Mainstream Court}

Multivariate statistical research on mainstream court sentencing provides substantial evidence in support of the focal concerns perspective, especially as an explanation for racial and ethnic disparities in the United States (Kautt and Spohn, 2007). The empirical studies show that racial/ethnic minorities are sentenced more harshly than others. For example, Hispanic and African American criminal defendants are more likely than 'whites' to be sentenced to prison (e.g. Spohn and Delone, 2010; Steffensmeier and Demuth, 2000). Findings of disparity against racial/ethnic minority defendants have led sentencing scholars in the United States to conclude that these statuses carry with them criminal stereotypes which are utilized subconsciously by judicial officers to make sentencing determinations. More specifically, attributions of increased blame and risk to ethnic/racial minorities is likely responsible for sentencing differentials between whites and non-whites (e.g. Steffensmeier and Demuth, 2001; Steffensmeier et.al, 1998).

In contrast to the extensive literature on racial/ethnic sentencing disparity in the United States, studies of the relationship between Indigenous status and sentencing are sparser. Over the last ten years there have been only a handful of Northern hemisphere investigations of Indigeneity and sentencing (in the United States, see Everett and Wojtkiewicz, 2002; Munoz and McMorris, 2002; Wilmot and Delone, 2010; Franklin, 2011; in Canada see, Weinrath, 2007; Welsh and Ogloff, 2008) (also see review by Jeffries and Bond, 2011a). Only three of these studies have examined the decision to imprison (Munoz and McMorris 2002 (US, misdemeanor sentencing); Welsh and Ogloff, 2008 (Canada); Franklin, 2011 (US Federal Courts). Overall, based on these few studies, there is evidence of negative discrimination in the decision to imprison for Native American offenders in the United States (Munoz and 
McMorris, 2002; Franklin, 2011; although conclusions based on Munoz and McMorris are limited by a failure to control for offenders’ past criminality). Like African American and Latino status characteristics, being Native American may also evoke perceptual shorthands about blame and risk. Unlike the United States' research, Welsh and Ogloff's (2008) Canadian study of the impact of 1996 statutory reforms around the sentencing of Aboriginal ${ }^{1}$ found sentencing equality between Aboriginal and non-Aboriginal Canadians. However, this finding arguably reflects Canadian higher court sentencing (and thus increased time available) rather than lower court (i.e. provincial), due to sample limitations. ${ }^{2}$

Compared to the United States and Canada, multivariate statistical analyses of the impact of Indigenous status on sentencing has been more prolific in Australia (see Bond and Jeffries, 2011a; Bond and Jeffries, 2011b; Bond and Jeffries, 2011c; Bond, Jeffries and Weatherburn, 2011; Bond and Jeffries, 2010; Jeffries and Bond, 2009; Jeffries and Bond, 2011a; Snowball and Weatherburn 2006, 2007). The vast majority of this research has focused on higher court sentencing, where either equality or leniency is found to be extended to Indigenous offenders (see review by Jeffries and Bond, 2011a).

Thus based on current research knowledge, and in contrast to the United States, there is little evidence of negative discrimination against Indigenous defendants sentenced in Australia and Canada, at least within the higher courts. Relying on the focal concern of practical constraints and consequences, differing political and community expectations have been hypothesized as

\footnotetext{
${ }^{1}$ In 1996, parliamentary reforms to the Canadian Criminal Code, which more broadly created a set of guidelines for the sentencing of all offenders, also made a specific provision recognizing the unique circumstances of Indigenous defendants: "all available sanctions other than imprisonment that are reasonable in the circumstances should be considered for all offenders, with particular attention to the circumstances of aboriginal offenders" (s.718.2(e))

${ }^{2}$ For example, the sample was drawn from an electronic legal database which did not contain all, especially less serious cases heard in busy courts, criminal sentencing decisions (for a fuller discussion, see Jeffries and Bond, 2011a).
} 
explaining why negative discrimination does not appear to be operating in the higher courts of these two countries (Jeffries and Bond, 2011a).

In both Canada and Australia, there is ongoing political and community concern about the over-representation of Indigenous peoples in prison (Anthony, 2010; Ives, 2004; Pfefferle, 2008; Vasey, 2003; Welsh and Ogloff, 2008). This broader contextual factor may have engendered a degree of judicial sensitivity, as evidenced by findings of sentencing leniency/equality, regarding the 'plight' of Indigenous peoples within the criminal justice system as a colonised group (e.g. see Jeffries and Bond, 2009; Jeffries and Bond, 2011a). In contrast, such concerns are not widely, if at all, expressed within the United States political context: Native Americans only constitute a small number of prisoners (compared to AfricanAmerican and Latino/a offenders) and many jurisdictions have introduced schemes that substantially minimise judicial sentencing discretion (Jeffries and Bond, 2011a).

Nonetheless, findings of negative sentencing discrimination against Indigenous Australians have recently been found within the context of the lower courts. Results from multivariate sentencing analyses in four Australian jurisdictions (Queensland, Western Australia, New South Wales and South Australia) ${ }^{3}$ show that Indigenous offenders are more likely to be incarcerated than non-Indigenous defendants when sentenced under like circumstances (e.g. similar past and current offending) (Bond and Jeffries, 2011; Jeffries and Bond, 2011b).

As described by Jeffries and Bond (2011c, 49), in contrast to judges in the Australian higher courts, lower court magistrates are required to make sentencing decisions under tighter time

\footnotetext{
${ }^{3}$ Like the United States and Canada, Australia has a federal system of government, with political power divided between a central government and six states plus two territories. Criminal law and criminal justice is primarily responsibility of State and territory governments.
} 
constraints and with less information. Sentencing determinations in Australia's lower courts are frequently made within a matter of minutes with information about defendants and their circumstances limited to brief statements made by defense counsel, the offender or police prosecutors. In contrast, higher court judges are often presented with extended pleas of aggravation and mitigation by defense counsel and prosecution, are provided with written or oral pre-sentence reports and victim impact statements, and may adjourn proceedings to consider the appropriate sentence. As suggested by the focal concerns perspective, when faced with such practical constraints, as time-poor magistrates are in the lower courts, 'perceptual shorthands' (i.e. community based stereotypes) to make sentencing determinations (Steffensmeier et al., 1998).

Perceptions of Indigenous peoples as 'deviant' pervade mainstream Australian society with Indigenous communities being seen as “troublesome”, “untrustworthy”, “dysfunctional”, “disintegrated”, “pathological” and "given to criminal conduct” (Cunneen, 2001; Jeffries and Bond, 2009; Jeffries and Bond, 2010). Thus, within the time pressured micro-level social environment of the lower court, these socially broader stereotypical assumptions could be drawn on subconsciously by magistrates to make sentencing determinations. In other words, and in contrast to their judicial colleagues in the higher courts, lower court magistrates simply do not have the luxury of pondering over the broader social and political ramifications of Indigenous over-representation in prison and associated marginalized position of this group in Australian society.

\section{Problem-Solving Courts}

Since the late 1980s, problem-solving courts been established in a number of western nations. These courts go by many names and take many forms. The United States has been a world 
leader in these new justice experiments, with Australia not far behind (Payne, 2005, 2006; Jeffries, 2005; Lee, 1999, 2000). In Australia, the first problem-solving court was the South Australian family violence court established in 1997 (see Payne 2005, 2006 for an overview of the development of problem-solving courts in Australia). In 1999, this was followed by the commencement of the New South Wales drug court program and South Australian mental impairment court. Since then problem-solving courts have emerged in all Australian jurisdictions and can be broadly categorized as including drug, family violence, mental health, child sex offences, Indigenous and homeless persons’ courts.

The popularization of therapeutic jurisprudence within the field of criminal justice (alongside changes in the broader socio-political environment) has provided the legitimacy and theoretical framework for the development of problem-solving courts both within and outside of Australia (see Jeffries, 2005). The fundamental principle underlying therapeutic jurisprudence is the selection of a therapeutic option that promotes well-being: tangible outcomes are sought for victims, offenders and society more broadly (Jeffries, 2005; Rottman and Casey, 2000; Stole, et.al., 2001; Wexler, 1993a, 1993b; Whitley, 1993; Wexler, 1992). One way this is considered achievable is through shifting court practice away from an adversarial to problem solving approach (Jeffries, 2005).

Hence unlike the mainstream criminal court system, problem-solving courts rely upon the active use of judicial authority to solve problems and to change offending behavior though the intensive involvement of judges/magistrates in every case (Jeffries, 2005). Problemsolving courts "represent a move towards a model of justice that recognizes the behavioral and environmental factors that contribute to offending, and the judicial systems capacity to deal with these problems” (Payne, 2006: 2). In contrast to mainstream criminal courts, problem solving courts use a team-based approach to offender treatment. Together, the 
judiciary, probation service, treatment providers, prosecution and defence attorneys (the problem-solving court team) develop a co-ordinated strategy to address the underlying causes of individuals' offending. This team-based approach has resulted in the creation of new judicial roles: no longer 'dispassionate, disinterested magistrates', judicial officers are now meant to be emphatic and engaged in the rehabilitative process (Bakht, 2004: 9; Jeffries, 2005). The judiciary, alongside the rest of the problem-solving court team is actively involved in the development of treatment programs. Regular monitoring of defendants' progress in, and compliance with, these programs are presented in the courtroom to judicial officers by various team members over multiple court sitting days. Depending on the problems that identified in individual defendants' cases, this could involve both actuarial (from actors such as probation officers) and clinical (from for example treatment providers) information. Thus, there is an on-going and extensive dialogue (both written and verbal) between judicial officers and the other members of the team involved in the treatment of defendants. Although this provides a context of broader "fact-finding" and more collaborative decision-making processes, judicial officers are ultimately responsible for making final sentencing determinations (King, 2010: 146). As is the case in the mainstream criminal courts, and consistent with the focal concerns perspective, these judicial sentencing determinations remain driven by judicial assessments of blameworthiness and risk, alongside a consideration of practical constraints and consequences (Australian Institute of Criminology, 2005: 7-79).

Thus, judicial officers making sentencing determinations within the problem-solving court environment are provided with more time and information about offenders and their cases (Jeffries, 2005; King, 2010). Based on the focal concerns perspective, the resulting hypothesis is that race/ethnicity/Indigeneity-based perceptual shorthands or stereotypes are 
less likely to impact sentencing determinations within the therapeutic environment of problem-solving courts. Yet to date, there have been no explorations of whether defendants' minority statuses influence sentencing decision making within these alternative court contexts. In this paper, we address this gap by reporting results of statistical analyses of Indigeneity and sentencing in the South Australian problem-solving criminal courts. Our research question is: does Indigeneity directly impact the decision to imprison in the problem-solving courts of South Australia, once differences in other relevant sentencing factors (e.g. current and past criminality) are taken into account? Based on the focal concerns perspective, we might anticipate that we should find close to parity in sentencing outcomes. As these courts spend more time, and access more detailed information about defendants, reliance on perceptual shorthands based on Indigeneity should be minimized.

\section{The Current Research}

We rely on data of adult cases ${ }^{4}$ resulting in a conviction between 2007 and 2009 in the South Australian problem solving courts (i.e. family violence, mental health and drug courts $^{5}$ ). In South Australia, the type of offence with which a person is charged determines the level of court in which they will be tried and sentenced. Offences are classified as summary (nonindictable) and indictable. A number of indictable offences can be dealt with summarily unless the prosecuting authority elects otherwise (Findlay et.al, 2009). Summary offences are generally considered minor because the sentencing penalties attached to them are at the lowest end of the sentencing scale. Those charged with summary offences are sentenced in what are generically referred to as the lower courts (e.g. Magistrates Courts) (Bond and

\footnotetext{
${ }^{4}$ Although our analyses are case-based, for ease of reference we will use the term "offender". We also adjust for the clustering introduced by the presence of repeat offenders in our analyses.

${ }^{5}$ The Nunga Court (or Indigenous Court) was not included in these analyses, as there is no variation in Indigenous status in this court.
} 
Jeffries, 2011b). All problem solving courts in South Australia come under the jurisdiction of the Magistrates Courts.

The study uses administrative court data provided by South Australian Office of Crime Statistics and Research. These data provide information on sex, Indigenous status, age, offence seriousness, prior criminal offending, plea, bail status and sentence type. For the study years of 2007 to 2009, there were 2,515 cases heard in a problem-solving court (excluding the Nunga, or Indigenous, Court). There were 417 (16.58\%) Drug Court cases, 942 (37.46\%) Family Violence Court cases, and 1,156 (45.96\%) Mental Impairment Court cases After missing data (less than 1\%), our final sample consists of 2,500 cases. Of these, about $10.20 \%$ were identified as Indigenous, and $19.92 \%$ were female. The average age of offenders was 33.81 years at the time of sentencing. Around $7.16 \%$ had a prison sentence imposed.

\section{Measures}

The dependent variable in this study is the decision to imprison. We use a dichotomous measure, comparing those who received a prison sentence (coded as 1) to those who did not (coded as 0).

Our analysis includes two categories of independent variables. (Their definition and coding is summarized in Table 1.) The first category consists of offender social characteristics: Indigenous status, sex and age at the time of disposition. Research suggests that both sex and age influence sentencing outcomes, making adjusting for these characteristics particularly important (e.g. Daly and Bordt, 1995; Steffensmeier et al., 1998; Johnson, 2003; Wu and Spohn, 2009). 


\section{[INSERT TABLE 1 ABOUT HERE]}

The second category of independent variables is case (or legal) characteristics. These include seriousness of principal offence ${ }^{6}$, presence of multiple conviction counts, prior criminal history, and bail status. To disentangle the direct effect of Indigenous status, it is crucial to control for case (legal) based factors, particularly current crime seriousness and criminal history (Mitchell, 2005; Spohn, 2000). Offence seriousness is frequently measured by statutory classifications, or other legally defined categories. We used the Australian National Offence Index (NOI) to measure the seriousness of an offender's principal offence. Developed by the Australian Bureau of Statistics, the NOI ranks the seriousness of all offence classifications defined by law (Australian Bureau of Statistics, 2009). The NOI ranking ranges from 1 (most serious) to 156 (least serious). To aid interpretation, we reverse-coded this index, so that higher scores indicate more serious offences. The presence of multiple conviction counts was included as an additional dichotomous measure of current offence seriousness. As can be found in past research on sentencing (e.g. Hagan, 1975; Albonetti, 1991; Ashworth, 1995; Jeffries, Fletcher and Newbold, 2003), prior criminal history was measured by two variables: the number of prior criminal convictions, and the presence of a prior term of imprisonment. Finally, refusal by police and other judicial officers to release offenders on bail may also influence judicial perceptions of risk and is therefore important to include in our analyses (Jeffries, Fletcher and Newbold, 2003; Jeffries and Bond, 2009). ${ }^{7}$

\footnotetext{
${ }^{6}$ By principal offence, we refer to the offence that received the highest sentencing penalty (ranked from 1-10 with 1 being imprisonment and 10 being no penalty) (see South Australian Office of Crime Statistics and Research, 2004:154) for a description). If two offences received the same penalty, the offence with the highest statutory penalty attached is recorded as the principal offence. If the charges are the same, the first charge is recorded as the principal offence (see South Australian Office of Crime Statistics and Research, 2004: 150).

${ }^{7}$ Plea of guilt was not included in our models as a requirement of referral to the problem-solving courts is either the presence of a guilty plea, or a strong indication that the defendant would change his/her plea to guilty at a later stage of the process. As demonstrated in our data, over 94\% of defendants (both Indigenous and non-Indigenous) already had a plea of guilt entered at the time of referral.
} 


\subsection{Results}

To explore the direct effect of Indigenous status on the decision to imprison in the problemsolving courts, we conduct our analyses in two stages. First, we examine the baseline differences between Indigenous and non-Indigenous defendants. Second, we identify the direct effect of Indigenous status on sentencing outcomes, adjusted for other sentencing factors.

Table 2 reports the descriptive statistics for the full sample, and by Indigenous status. As shown in Table 2, there was no statistically significant difference in the proportions of Indigenous and non-Indigenous cases which received a prison sentence. However, there were some differences between Indigenous and non-Indigenous cases in social and case characteristics. For instance, Indigenous cases were more likely to be female and younger, than non-Indigenous cases. Indigenous cases had more extensive criminal histories and more serious current offending (although these differences were significant at $\mathrm{p}<0.10$ ). Compared to non-Indigenous offenders, Indigenous offenders were also less likely to be out on bail at some stage of their cases.

[INSERT TABLE 2 ABOUT HERE]

\section{Direct Effect of Indigeneity in the Problem-Solving Courts}

A series of sequential logistic regression models were estimated to identity the direct effect of Indigeneity on the likelihood of an imprisonment order (versus a non-imprisonment order), 
controlling for offender characteristics, prior and current offender and court processing factors. ${ }^{8}$ The results are reported in Table 3.

\section{[INSERT TABLE 3 ABOUT HERE]}

Model 1 provides a baseline model, estimating the impact of Indigenous status controlling for sex and age (see Table 3). Similarly to the bivariate results (see Table 2), there is no significant direct effect of Indigenous status on the decision to imprison. Neither sex nor age had a significant impact on the odds of imprisonment, after adjusting for Indigenous status. ${ }^{9}$

Model 2 estimates the full model, adding case characteristics to explore how these critical legal variables impact on the effect of Indigenous status on the decision to imprison. Consistent with past mainstream court research, offenders with more extensive criminal histories (as measured by number of prior convictions and presence of prior imprisonment) and current offence seriousness (as measured by seriousness score and presence of multiple counts) significantly increase the likelihood of a prison sentence (e.g. Mitchell, 2005; Spohn, 2000). For example, offenders with a prior term of imprisonment are almost 4 times as likely to have a prison sentence (versus a non-prison order) than those without a prior history of imprisonment. Offenders convicted of multiple counts are over 6 times as likely to receive a prison sentence, compared to offenders with a single conviction count. Not being released on bail also has a significant impact, increasing the odds of a prison sentence compared to offenders who were released on bail (Jeffries, Fletcher and Newbold, 2003; Jeffries and Bond, 2009). Also commensurate with prior sentencing studies youthfulness increased the

\footnotetext{
${ }^{8}$ We were not able to correct for selectivity in our models, as we did not have data on the preceding decision point (the decision to convict). However, correction for selection bias relies on theoretically appropriate exclusion restrictions which are often not available to researchers, and as a result, uncorrected estimates can be more accurate than in appropriately corrected estimates (Bushway, Johnson and Slocum, 2007). Thus, uncorrected estimates are presented here.

${ }^{9}$ We note that, due to the use of robust standard errors, larger estimates will be required to achieve conventional levels of significance.
} 
probability of incarceration (Steffensmeier et al., 1998; Johnson, 2003; Wu and Spohn, 2009). However, contrary to prior mainstream court studies, sex does not have a separate unique direct effect on the decision to imprison in the problem-solving courts (e.g. Daly and Bordt, 1995 and in Australia, Jeffries and Bond, 2010).

Of particular interest, however, is the effect of including case characteristics on the impact of Indigenous status on the likelihood of a prison sentence. By accounting for differences in case characteristics, such as past and current criminality, Indigenous status has a direct unique effect on the decision to imprison. Indigenous offenders are 0.462 times as likely to receive an imprisonment order (versus a non-imprisonment order) compared to nonIndigenous offenders in statistically similar circumstances. Thus, although baseline differences indicated no significant difference in the decision to imprison between Indigenous and non-Indigenous cases, we found a significant direct effect of leniency once we account for differences in other factors. This finding suggests that differences in legal factors may be suppressing the direct effect of Indigenous status in this context.

\subsection{Discussion}

According the theoretical perspective of focal concerns, time poor judicial officers likely rely of perceptual shorthands (i.e. societal stereo-types) of offenders when determining whether or not to sentence them to prison. Researchers generally treat a finding of the harsher sanctioning of minority group defendants as evidence of the operation of these perceptual shorthands, especially in the United States context. Here, mainstream courts research consistently shows that in contrast to whites, African, Latino and Native Americans are more likely to be sentenced to prison even when they appear before the court under statistically comparable circumstances. 
Unlike the United States, results of minority group sentencing studies in Canada and Australia are mixed. Here, Indigenous/non-Indigenous equality/leniency is generally found in studies of mainstream higher court sentencing with disparity the more likely outcome of lower court studies. Consistent with the perceptual short-hand argument within focal concerns, Australian researchers have hypothesized that contrasting outcomes by court level (i.e. higher versus lower) likely reflect differences in time pressure between organizational contexts. In other words, higher court judges have more time than lower court magistrates to determine offenders and their circumstances before ruling on a sentence (Jeffries and Bond, 2011b; 2011c).

Unlike the mainstream courts, the sentencing environment within a problem-solving court is theoretically underpinned by the notion of therapeutic jurisprudence. Being 'therapeutic' requires more judicial contemplation about offenders and their cases before reaching a decision about sentencing. As such, judicial officers within the problem-solving court environment are, compared to the mainstream court, provided with more time and information. Thus, we would expect that perceptual shorthands about minority group statuses would less likely impact sentencing in the problem-solving courts. At the very least, we would expect to find equality in sentencing between majority and minority groups within problem-solving courts.

Evidence supporting this argument is provided by the current research. Results from our multivariate analyses of Indigeneity and sentencing in the problem-solving courts of South Australia show a direct relationship between Indigenous status and the likelihood of imprisonment, with leniency being extended to Indigenous offenders. Indigenous defendants- 
sentenced in the problem solving courts were less likely to be sentenced to prison than similarly positioned non-Indigenous defendants.

Thus, the current research lends support to the organizational constraint/perceptual shorthand argument within focal concerns. Unlike the time poor sentencing environment of the mainstream South Australian lower courts (where previous research shows negative disparity against Indigenous offenders in the decision to imprison, see Jeffries and Bond, 2011b, 2011c), the current finding is commensurate with leniency found at the South Australian higher court level (see Jeffries and Bond, 2009). Unlike magistrates in the lower courts, higher court sentencing judges and magistrates in the problem-solving courts have more time and detailed information about offenders and their circumstances. This likely enables a deeper consideration of the unique personal and social circumstances of Indigenous offenders and reduces judicial propensity to draw on crude populist stereo-typical assumptions (Jeffries and Bond, 2011b, 2011c, Jeffries and Bond, 2009).

Clearly findings of the current research have a degree of theoretical significance in terms of lending further salience to the focal concerns perspective. Further, there are implications for existing policy. If racial/minority/Indigenous sentencing disparities can be reduced through initiatives such as problem-solving courts, then a case can be made for the extension and development of strategies that allow for a more considered approach to sentencing. However, further research is required.

The current study is the first to consider the impact of a minority group status on sentencing in the problem-solving courts, but is limited to an exploration of Indigenous status in one Australia state. Our results could be unique to the sentencing of Indigenous defendants within 
the South Australian problem-solving court environment. Further, while consideration was given to what are generally seen as the most significant sentencing indicators (e.g. criminal history and current crime seriousness), other variables thought to be important to judicial decision making were not available for inclusion in our analyses because they were not available in the court administrative data-base. In particular, other key social history and offence context variables that may have impacted judicial focal concerns about blame, risk, and practical constraints could not be included. For example, personal histories of abuse and victimization, strong familial ties (including having responsibility for the care of others), employment status, circumstances under which the offence occurred (including whether there were co-offenders involved; whether the offence occurred in a private residence; whether there was evidence of premeditation; and whether there was any physical injury caused to a victim) (see for example, Kruttschnitt, 1982; Allen 1987; Daly, 1989; Jeffries, Fletcher and Newbold, 2003; Jeffries and Bond, 2009; Jeffries and Bond, 2010). Although their absence is not unusual in sentencing research, the inclusion of a wider range of sentencing factors in our models may have helped to explain the Indigenous effect.

\section{Conclusion}

From a focal concerns perspective, the therapeutic context of problem-solving courts could reduce judicial reliance on perceptual shorthands and along with it, the likelihood of negative sentencing discrimination against minority groups. However, sentencing disparities scholars have been silent on the issue of sentencing in the problem-solving courts with attention focused on the mainstream courts. Further research is required to more fully explore the impact of minority group statuses (including Indigenous, African American, Latino) on the likelihood of receiving prison terms within therapeutic court contexts. 


\section{Acknowledgments}

This research would not have been possible without the support of a research grant from the Australian Criminology Research Council (CRC 11/09-10) and the data supplied by the South Australian Office of Crime Statistics and Research. The Criminology Research Council had no input into the study design, data collection, analysis or interpretation of data, writing of or decision to submit this paper for publication. We would also like to extend our specific appreciation to Paul Thomas and Ingrid Ahmer from the South Australian Office of Crime Statistics and Research for providing data access and support.

\section{References}

Allen, H., 1987. Justice Unbalanced: Gender, Psychiatry and Judicial Decisions. Open University Press, Philadelphia.

Alvarez, A., Bachman, R.D., 1996. American Indians and sentencing disparity: an Arizona test. Journal of Criminal Justice 24 (6), 549-561.

Anthony, T., 2010. Sentencing Indigenous offenders. Indigenous Clearinghouse Brief, 7 March 2010. New South Wales Justice and Attorney General, Sydney.

Ashworth, A., 1995. Sentencing and Criminal Justice, second ed. Butterworths, London.

Australian Bureau of Statistics. (2009). National Offence Index, 2009. Canberra: Australian Bureau of Statistics. 
Australian Institute of Criminology. 2005. Specialty Courts in Australia: Report to the Criminology Research Council. Canberra: Australian Institute of Criminology.

Bakht, N. 2004. Problem Solving Courts as Agents of Change. Ontario: National Judicial Institute

Bond, C., Jeffries, S., 2010. Sentencing Indigenous and non-Indigenous women in Western Australia’s higher courts. Psychiatry, Psychology and Law, 17 (1), 70-78.

Bond, C., Jeffries, S., 2011a. Indigeneity and the likelihood of imprisonment in Queensland's adult and children's courts. Psychiatry, Psychology and Law. On-Line First, DOI: 10.1080/13218719.2010.543757.

Bond, C., Jeffries, S., 2011b. Indigeneity and the judicial decision to imprison: a study of Western Australia’s higher courts. British Journal of Criminology, 51 (2), 256-277

Bond, C., Jeffries, S., 2011c. Harsher sentences? Indigeneity and prison sentence length in Western Australia's higher courts. Journal of Sociology, On-Line First, DOI:10.1177/1440783311413486, 1-21.

Bond, C., Jeffries, S., 2011d. Assessing risk and blameworthiness in the sentencing of criminal defendants: an exploratory study in Western Australia's higher courts. Current Issues in Criminal Justice 23 (1), 17-36. 
Bond, C., Jeffries, S., Weatherburn, D., 2011. How much time? Indigenous status and the sentenced imprisonment term decision in New South Wales. Australian and New Zealand Journal of Criminology, 44 (2), 272-290.

Bushway, S., Johnson, B., Slocum, L., 2007. Is the magic still there? The use of the Heckman two-step correction for selection bias in criminology. Journal of Quantitative Criminology, 23, 151-173.

Daly, K., 1989. Rethinking judicial paternalism: gender, work-family relations, and sentencing. Gender and Society, 3 (1), 9-36.

Daly, K., 1994. Gender, Crime, and Punishment. Yale University Press, New Haven.

Eaton, M., 1987. Justice for Women? Family; Court and Social Control. Open University Press, Milton Keynes.

Everett, R.S., Wojtkiewicz, R.A., 2002. Difference, disparity, and race/ethnic bias in federal sentencing. Journal of Quantitative Criminology, 18 (2), 189-211.

Franklin, T.W., 2011. Sentencing Native Americans in US Federal Courts: An Examination of Disparity. Justice Quarterly, DOI:10.1080/07418825.2011.605072.

Hagan, J., 1975. The social and legal construction of criminal justice: a study of the presentencing process. Social Problems, 22 (5), 620-637. 
Hawkins, D., 1987. Beyond anomalies: rethinking the conflict perspective on race and criminal punishment. Social Forces, 65 (3), 719-745.

Ives, D.E., 2004. Inequality, crime and sentencing: Borde, Hamilton and the relevance of social disadvantage in Canadian sentencing law. Queen’s Law Journal, 30, 114-155.

Jeffries, S., 2002a. Does gender really matter?: criminal court decision making in New Zealand. New Zealand Sociology, 17 (1), 135-149.

Jeffries, S., 2002b. Just or unjust?: problematising the gendered nature of criminal justice. Women’s Studies Journal, 18 (1), 24-41.

Jeffries, S., 2005. How justice 'gets done': politics, managerialism, consumerism, and therapeutic jurisprudence. Current Issues in Criminal Justice, 17 (2), 254-268.

Jeffries, S., Bond, C., 2010. Sex and sentencing in South Australia’s higher courts. Current Issues in Criminal Justice, 22 (1), 81-97.

Jeffries, S., Bond, C., 2011a. The impact of Indigenous status on adult sentencing: a review of the statistical research literature from the United States, Canada and Australia. Journal of Ethnicity in Criminal Justice (In Press).

Jeffries, S., Bond, C., 2011b. Indigenous disparity in lower court imprisonment decisions: a study of two Australian jurisdictions, 1998 to 2008. Trends and Issues in Criminal Justice (Under Review). 
Jeffries, S., Bond, C., 2011c. The Sentencing of Indigenous Offenders in the Lower Courts: A Study of Three Australian Jurisdictions: Report to the Criminology Research Council. Australian Institute of Criminology, Canberra (In Press).

Jeffries, S., Bond, C., 2010. Narratives of mitigation: sentencing Indigenous criminal defendants in South Australia’s higher courts. Journal of Sociology, 46 (3), 219-237.

Jeffries, S., Bond, C., 2009. Does Indigeneity matter?: sentencing Indigenous offenders in South Australia’s higher courts. Australian and New Zealand Journal of Criminology, 42 (1), 47-71.

Jeffries, S., G. Fletcher., Newbold, G., 2003. Pathways to sex-based discrimination in criminal court sentencing. Criminology, 41 (2), 329-353.

Johnson, B.D., 2003. Racial and ethnic disparities in sentencing departures across modes of conviction. Criminology, 41 (2), 449-489.

Johnson, B.D., 2006. The multilevel context of criminal sentencing: integrating judge and county-level influences. Criminology, 44 (2), 259-298.

Johnson, B.D., Ulmer, J.T., Kramer, J.H., 2008. The social context of guidelines circumvention: the case of federal district courts. Criminology, 46 (3), 737- 783. 
Kautt, P., Spohn, C., 2007. Assessing blameworthiness and assigning punishment: theoretical perspectives on judicial decision making, in: Duffee, D., Maguire, E. (Eds.), Criminal Justice Theory: Explaining the Nature and Behaviour of Criminal Justice. Routledge, New York, pp. 155-180.

King, M.S., 2010. Judging, judicial values and judicial conduct in problem-solving courts, Indigenous sentencing courts and mainstream courts. Journal of Judicial Administration, 19, 133-159.

Kruttschnitt, C., 1982. Women, crime, and dependency: an application of the theory of law. Criminology, 19 (4), 495-513.

Kramer, J., Ulmer, J., 2002. Downward departures for serious violent offenders: local court corrections to Pennsylvania’s sentencing guidelines. Criminology, 40 (4), 897-932.

Lee, E., 2000. Community courts: an evolving model. Community Justice Series 2, Bureau of Justice Assistance Monograph. US Department of Justice Office of Justice Programs, Washington.

Lee, M., 1999. The fear of crime and self-governance: towards a genealogy. The Australian and New Zealand Journal of Criminology, 32 (3), 227-246.

MacKenzie, G., 2005. How Judges Sentence. Federation Press, Annandale. 
Mitchell, O., 2005. A meta-analysis of race and sentencing research: explaining the inconsistencies. Journal of Quantitative Criminology, 21 (4), 439-466.

Munoz, E., McMorris, B., 2002. Misdemeanor sentencing decisions: The cost of being Native American. The Justice Professional, 15 (3), 239-259.

Nolan, J.L., 2001. Reinventing Justice: The American Drug Court Movement. Princeton University Press, New Jersey.

Payne, J., 2005. Specialty Courts in Australia: Report to the Criminology Research Council. Australian Institute of Criminology, Canberra.

Payne, J., 2006. Specialty courts: current issues and future prospects. Trends and Issues in Criminal Justice. Australian Institute of Criminology, Canberra.

Pfefferle, B., 2008. Gladue sentencing: uneasy answers to the hard problem of Aboriginal over-incarceration. Manitoba Law Journal, 32 (2), 113-143.

Rottman, D., Casey, P., 2000. Therapeutic jurisprudence and the emergence of problemsolving courts. Corrections Forum, 9 (2), 27-30.

Snowball, L., Weatherburn, D., 2006. Indigenous over-representation in prison: The role of offender characteristics. Contemporary Issues in Crime and Justice, 99. New South Wales Bureau of Crime Statistics and Research, Sydney. 
Snowball, L., Weatherburn, D., 2007. Does racial bias in sentencing contribute to Indigenous overrepresentation in prison? Australian and New Journal of Criminology, 40 (3), 272-290.

South Australian Office of Crime Statistics and Research, 2004. Crime and Justice in South Australia, 2003: Adult Courts and Corrections. South Australian Office of Crime Statistics and Research, Adelaide.

Spohn, C.C., 2000, Thirty years of sentencing reform: the quest for a racially neutral sentencing process. Policies, Processes, and Decisions of the Criminal Justice System, 3. U.S. Department of Justice, Washington, DC.

Spohn, C., Delone, M., 2000. When does race matter?: an examination of the conditions under which race affects sentence severity. Sociology of Crime, Law and Deviance, 2, 3-37.

Steffensmeier, D., Demuth, S., 2000. Ethnicity and sentencing outcomes in U.S. federal courts: who is punished more harshly? American Sociological Review, 65 (5), 705-729.

Steffensmeier, D., Demuth, S., 2001. Ethnicity and judges’ sentencing decisions: hispanicblack-white comparisons. Criminology, 39 (1), 145-178.

Steffensmeier, D., Ulmer, J., Kramer, J., 1998. The interaction of race, gender, and age in criminal sentencing: the punishment cost of being young, black, and male. Criminology, 36 (4), 763-797.

Stole, D., Wexler, D., Winick, B., 2001. The heart of the problem. ABA Journal, 87, 79-80. 
Ulmer, J.T., Kurlychek, M., Kramer, J., 2007. Prosecutorial discretion and the imposition of mandatory minimums. Journal of Research in Crime and Delinquency, 44 (4), 427-458.

Vasey, A., 2003. Rethinking the sentencing of Aboriginal offenders: The social value of s.718(e). Windsor Review of Legal and Social Issues, 73, 73-97.

Weinrath, M., 2007. Sentencing disparity: Aboriginal Canadians, drink driving and age. Western Criminology Review, 8 (2), 16-28.

Welsh, A., Ogloff, J., 2008. Progressive reforms or maintaining the status quo? An empirical evaluation of the judicial consideration of Aboriginal status in sentencing decisions. Canadian Journal of Criminology and Criminal Justice, 50 (4), 491-517.

Wexler, D.B., 1992. Justice, mental health and therapeutic jurisprudence. Cleveland State Law Review, 40, 517-526.

Wexler, D.B., 1993a. New directions in therapeutic jurisprudence: breaking the bounds of conventional mental health law scholarship. New York Law School Journal of Human Rights, 35 (1), 759-778.

Wexler, D.B., 1993b. Therapeutic jurisprudence and the criminal Courts. William and Mary Law Review, 35, 279-299. 
White, R., Perrone, S., 2005. Crime and Social Control, second ed. Oxford University Press, Melbourne.

Whitley, A.B., 1993. Therapeutic jurisprudence: a new approach to the criminal law. American Journal of Criminal Law, 20, 303-306.

Wilmot, K.A., Delone, M.A., 2010. Sentencing Native Americans: a multistage analysis under the Minnesota sentencing guidelines. Journal of Ethnicity in Criminal Justice, 8 (3), 151-180.

Wu, J., Spohn, C., 2009. Does an offender's age have an effect on sentence length?: a metaanalytic review. Criminal Justice Policy Review, 20 (4), 379-413. 
Table 1. Description of Study Variables, South Australian Problem-Solving Courts (2007-2009, $\mathrm{N}=2,501)$

\begin{tabular}{|c|c|}
\hline Variables & Description \\
\hline \multicolumn{2}{|l|}{ Dependent variable } \\
\hline Sentence of imprisonment order & $0=$ no, not sentenced to imprisonment; $1=y e s$, sentenced to imprisonment. \\
\hline \multicolumn{2}{|l|}{ Independent variables } \\
\hline \multicolumn{2}{|l|}{ Offender social characteristics } \\
\hline Indigenous status & $\begin{array}{l}0=\text { =non-Indigenous; } 1=\text { Indigenous. Indigenous status is based on self- } \\
\text { identification from July 2007, and on apprehending police officer's } \\
\text { assessment of offenders' physical appearance (prior to July 2007). }\end{array}$ \\
\hline Sex & $0=$ male; $1=$ female. \\
\hline Age & At time of disposition (in years). \\
\hline \multicolumn{2}{|l|}{ Case characteristics } \\
\hline Prior convictions & Number of all prior convictions known. \\
\hline Has prior term of imprisonment & $0=$ no prior imprisonment term; $1=$ at least one prior imprisonment term. \\
\hline Seriousness of principal offence & Reverse coded National Offence Index (NOI). \\
\hline Convicted of multiple counts & $0=$ no; $1=$ yes. \\
\hline Not granted bail & $\begin{array}{l}0=\text { no; } 1=\text { yes. Refers to whether or not bail was ever cancelled, excluded, } \\
\text { revoked, ineligible, or refused at any stage of the court process. }\end{array}$ \\
\hline
\end{tabular}


Table 2. Descriptive Statistics by Indigenous Status in the South Australian ProblemSolving Courts (2007-2009, $N=2,500)$

\begin{tabular}{|c|c|c|c|c|}
\hline & Total cases & Indigenous cases & $\begin{array}{l}\text { Non-Indigenous } \\
\text { cases }\end{array}$ & Difference \\
\hline \multicolumn{5}{|l|}{ Social history } \\
\hline \% Indigenous & 10.16 & --- & --- & \\
\hline$\%$ female & 19.72 & 32.68 & 18.25 & $14.42^{* * *}$ \\
\hline Mean age at disposition & $33.77(9.56)$ & $31.96(8.52)$ & $33.97(9.66)$ & $2.01^{* *}$ \\
\hline \multicolumn{5}{|l|}{ Current and past offending } \\
\hline Mean prior convictions & $28.12(33.44)$ & 31.85 (39.77) & $27.70(32.63)$ & $4.34^{\#}$ \\
\hline$\%$ prior imprisonment term & 67.55 & 37.80 & 32.01 & $5.78^{\#}$ \\
\hline Mean seriousness of current offence & $74.88(40.74)$ & $79.27(40.05)$ & 74.32 (40.79) & $4.96^{\#}$ \\
\hline \% with multiple conviction counts & 32.60 & 50.79 & 49.55 & 1.23 \\
\hline \% not released on bail & 26.44 & 36.22 & 25.33 & $10.89^{* * *}$ \\
\hline \multicolumn{5}{|l|}{ Sentence outcome } \\
\hline$\%$ with a prison sentence & 7.16 & 5.51 & 7.35 & 1.83 \\
\hline Total number of cases & 2,500 & 254 & 2,246 & \\
\hline
\end{tabular}

Notes:

1. Table reports summary statistics for the problem-solving courts in South Australia, except for the Nunga (Indigenous) Court.

2. Means (with standard deviations in brackets) are reported for continuous variables; percentages are reported for dichotomous variables.

3. T-tests for difference between group means, and z-test for difference between group proportions, are used to test whether there is a significant difference between Indigenous and non-Indigenous cases. 
Table 3. Likelihood of an Imprisonment Order on Key Offender and Case Characteristics, Principal Offence, South Australian Problem-Solving Courts (20072009, $N=2,500$ )

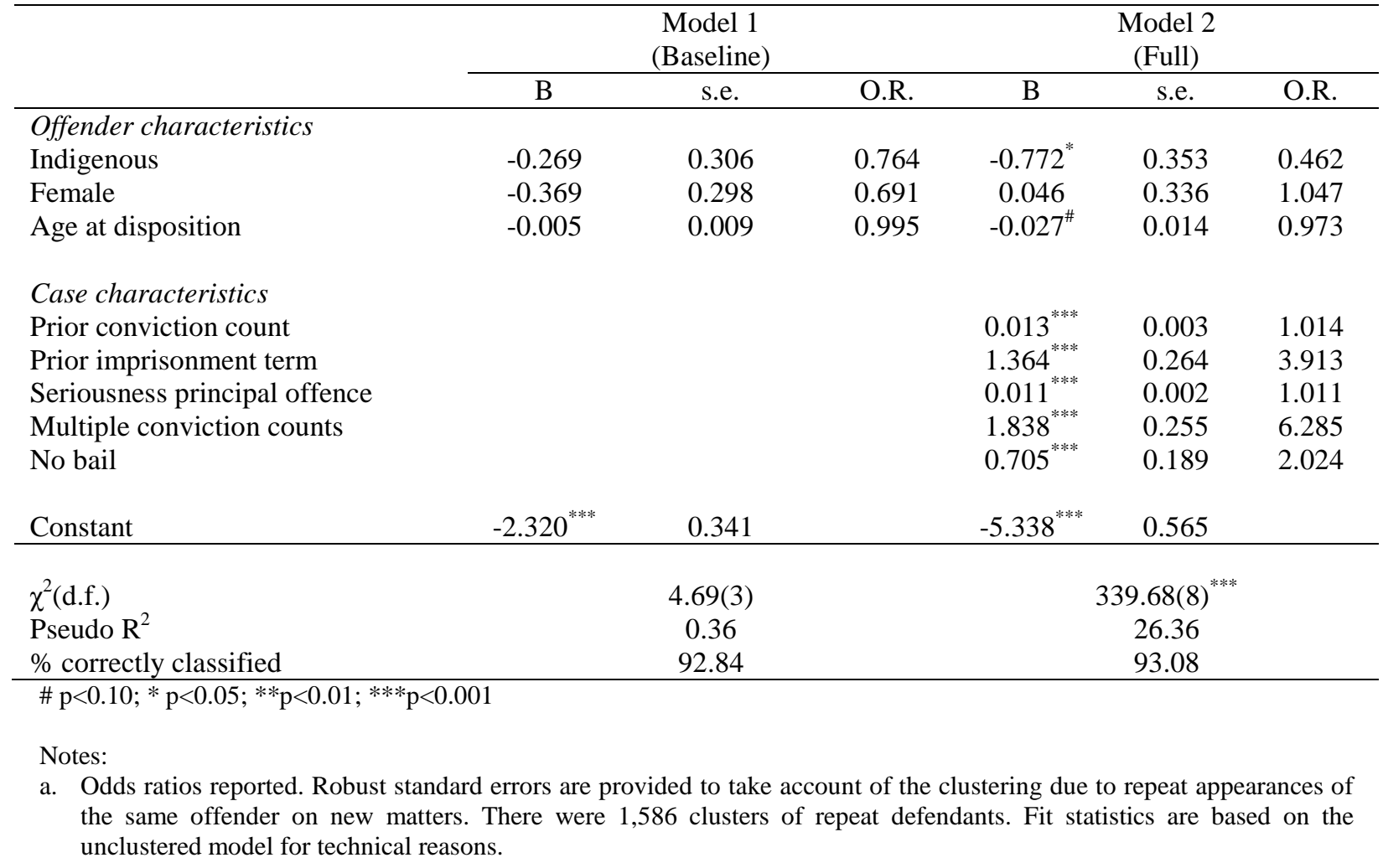

